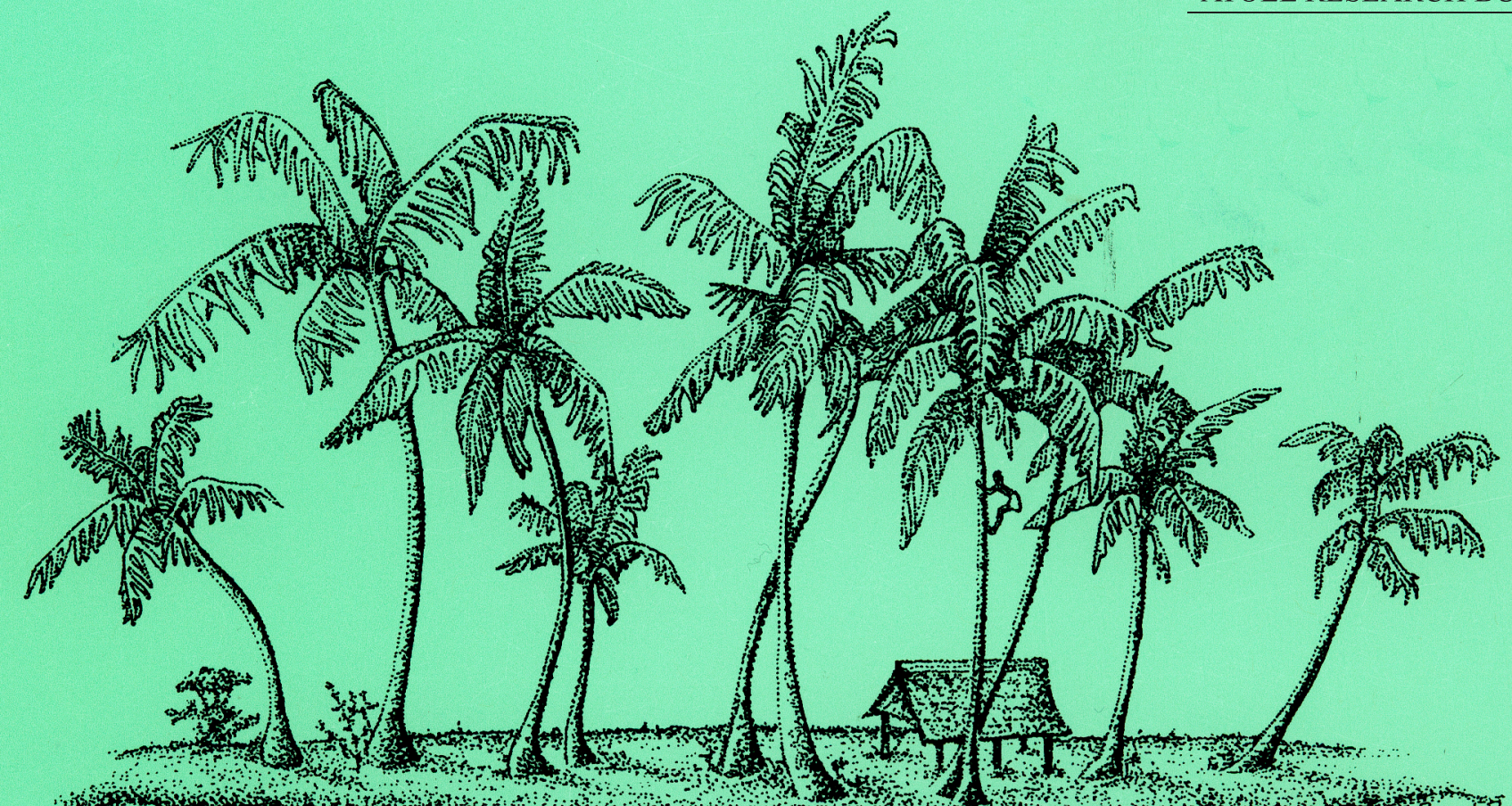

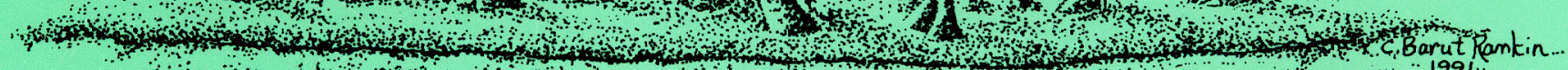
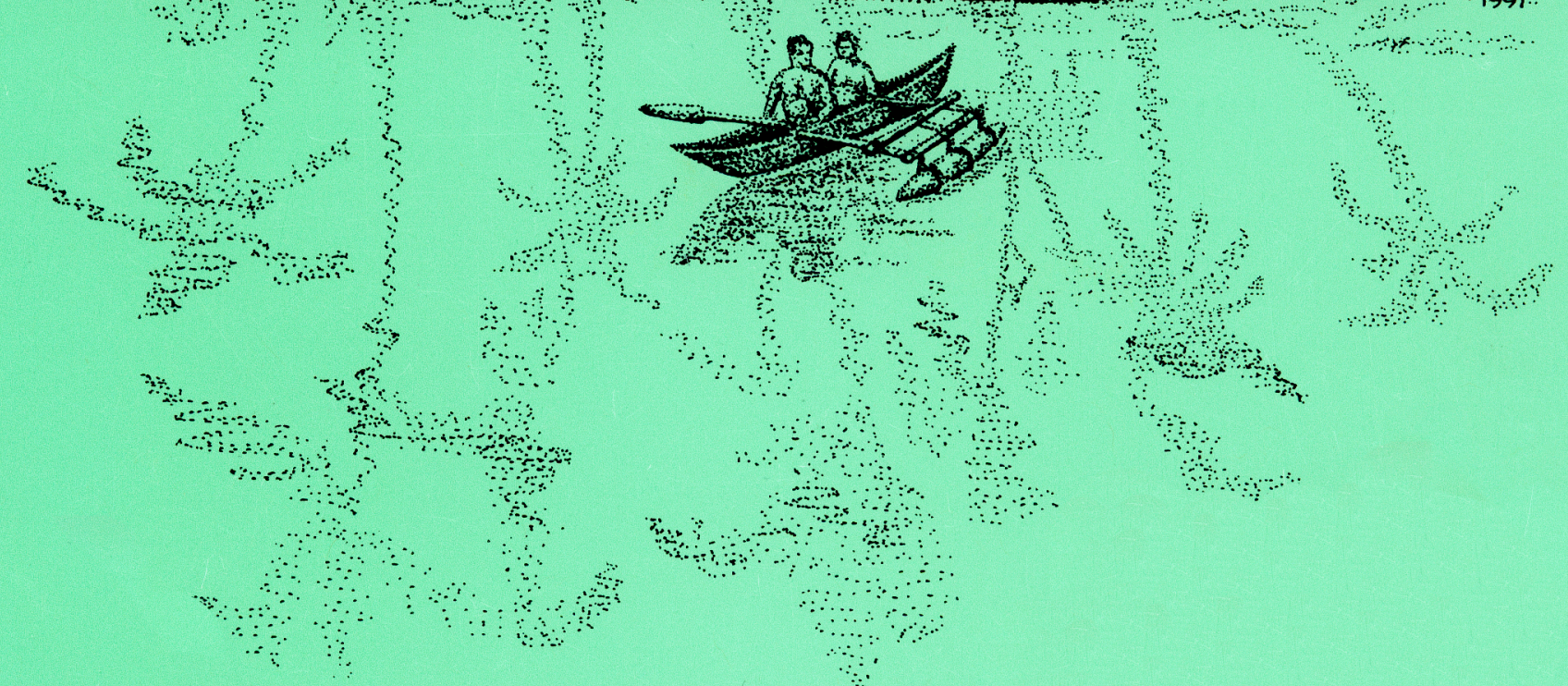

REPORT ON MENJANGAN ISLAND'S CORAL REEF:

A BALI BARAT NATIONAL PARK MARINE PROTECTED AREA

ATOLL

Orla Doherty, Carol Milner, Phillip Dustan, Stuart Campbell,

Shinta Pardede, Tasrif Kartawijaya and Abigail Alling

RESEARCH

Smithsonian Institution
Scholarly Press

BULLETIN 


\section{REPORT ON MENJANGAN ISLAND'S CORAL REEF:}

\section{A BALI BARAT NATIONAL PARK MARINE PROTECTED AREA}

Orla Doherty, Carol Milner, Phillip Dustan, Stuart Campbell, Shinta Pardede, Tasrif Kartawijaya and Abigail Alling

Atoll Research Bulletin No. 599 • 19 November 2013 
All statements made in papers published in the Atoll Research Bulletin are the sole responsibility of the authors and do not necessarily represent the views of the Smithsonian Institution or of the editors of the Bulletin. Articles submitted for publication in the Atoll Research Bulletin should be original papers and must be made available by authors for open access publication. Manuscripts should be consistent with the "Author Formatting Guidelines for Publication in the Atoll Research Bulletin." All submissions to the Bulletin are peer reviewed and, after revision, are evaluated prior to acceptance and publication through the publisher's open access portal, Open SI (http://opensi.si.edu).

Published by SMITHSONIAN INSTITUTION SCHOLARLY PRESS

P.O. Box 37012, MRC 957

Washington, D.C. 20013-7012

www.scholarlypress.si.edu

The rights to all text and images in this publication are owned either by the contributing authors or third parties. Fair use of materials is permitted for personal, educational, or noncommercial purposes. Users must cite author and source of content, must not alter or modify the content, and must comply with all other terms or restrictions that may be applicable. Users are responsible for securing permission from a rights holder for any other use.

ISSN: 0077-5630 (online) 


\title{
REPORT ON MENJANGAN ISLAND'S CORAL REEF: A BALI BARAT NATIONAL PARK MARINE PROTECTED AREA
}

\author{
ORLA DOHERTY ${ }^{1}$, CAROL MILNER ${ }^{1}$, PHILLIP DUSTAN ${ }^{2}$, STUART CAMPBELL ${ }^{3}$, SHINTA \\ PARDEDE $^{3}$, TASRIF KARTAWIJAYA ${ }^{3}$ and ABIGAIL ALLING ${ }^{1}$
}

\begin{abstract}
Menjangan Island is located off the coast of NW Bali. The island and surrounding waters lie within a Marine Protected Area (MPA), as part of the Bali Barat National Park (BBNP), officially formed in 1984. Although many organizations have surveyed this reef area over the span of four decades, this is the first time that data on reef quality is compared over a nine year timeframe, from 2002 until 2011.

From 19 March to 10 April 2011, eleven sites were studied: eight were located within Bali Barat National Park (BBNP) and three were located outside. The sites were clustered into areas identified as "BBNP Menjangan Is.” (sites surrounding Menjangan Island), "BBNP Sumber Klampok” (sites adjacent to the mainland) and "Sumber Kima" (sites outside the MPA). Sites within BBNP Menjangan Is. contained the highest mean cover of live hard corals (42\%) although these sites also had the highest incidence of damaged coral colonies and of fishing gear. Comparisons of the benthic substrate data in 2011 with data collected in 2002 suggests that there was an overall increase in coral coverage in each of the 3 areas, as well as an increase in the damage to live hard corals. The two areas within BBNP had more than twice as much fish biomass in comparison with the area outside BBNP. Using the Index of Fish Diversity in the Indo Pacific region (CFDI; Allen and Werner, 2002), fish species were judged to be moderately diverse within the BBNP and poorly diverse outside.

Although Menjangan Island lies within an MPA where no fishing is allowed, there is no enforcement of the no-take zone or prevention of anchoring by visitors to the island, and even as recently as July 2009 blast fishing was observed (pers. comm.). To help maintain the area as a reservoir for biodiversity as well as maintain the economic viability for the people of NW Bali, the Biosphere Foundation initiated a community-based conservation program called "Friends of Menjangan" with Yayasan Dwi Asih Sejahtera, a local Non-Governmental Organization (NGO). This community-based conservation movement is led by members of the local community, with approval from BBNP and participation by all stakeholders.
\end{abstract}

Key Words: coral reef, conservation, MPA, research, community outreach, Menjangan Island, Bali, Indonesia, Southeast Asia.

\section{INTRODUCTION}

\section{Indonesia and the Coral Triangle}

The waters of Indonesia contain the second largest coral reef area in the world $\left(51000 \mathrm{~km}^{2}\right.$; Burke et al., 2002) but unlike neighboring Australia, which has the largest and arguably the most protected reef, Indonesian reefs are the most threatened in the world. This is largely due to overfishing and destructive fishing practices, as well as unchecked development causing pollution and sedimentation (Burke et al.,

\footnotetext{
${ }^{1}$ Biosphere Foundation, PO Box 808, Big Pine, CA 93513, USA

${ }^{2}$ Department of Biology, College of Charleston, Charleston, SC 29424, USA

${ }^{3}$ Indonesia Marine Program, Wildlife Conservation Society, Jalan Padang Linjong 60B, Canggu, Bali, Indonesia
} 
2011). According to a survey conducted in 2010 by the Ministry of Marine Affairs and Fisheries, only 6\% of Indonesian reefs are still in excellent condition (Anon., 2010). Of the remaining reefs, 30\% are in good condition and $64 \%$ have been categorized as damaged. Given that $60 \%$ of the country's population of 240 million people relies on the sea and its coral reefs for their livelihoods, Indonesia is considered to be one of the countries most vulnerable to the effects of coral reef degradation (Burke et al., 2011).

A large area of the earth's tropical seas has been dubbed the "Coral Triangle" (CT) because it contains the greatest wealth of coral reef species, marine biodiversity and abundance (Fig. 1; Anon., n.d.). It stretches from Indonesia to the Solomon Islands in the Pacific Ocean and is sometimes called the "Amazon of the Seas." Although it represents just 1\% of the Earth's surface area, the CT is home to more than 600 of the nearly 800 species of reef-building coral found worldwide. It hosts 3,000 species of fish (Dirhamsyah et al., 2012) and the largest area of mangrove forests in the world (Giri et al., 2011). It is truly the coral reef epicenter on planet Earth. This richness has also made it a major nursery and migratory route for tuna, billfish, turtles, whales, dolphins, manta rays, whale sharks, dugongs and many other marine mega fauna. These creatures come to breed and feed in the nourishing and sheltered waters of the CT.

The Coral Triangle is also at the epicenter of a potential ecological crisis. Within it, the level of threat to coral reefs due to human activity is estimated to have reached a staggering $88 \%$ (Burke et al., 2002). Scientists predict that these reefs will disappear by the end of this century if no further conservation efforts are made (Hoegh-Guldberg et al., 2009). In response to these threats the "Coral Triangle Initiative" (CTI) was launched in December 2007 in Bali. Priority geographical areas were declared within the Coral Triangle according to levels of biodiversity and fisheries value and one of these is Bali's Marine Protected Area (MPA) Network, which includes Menjangan Island.

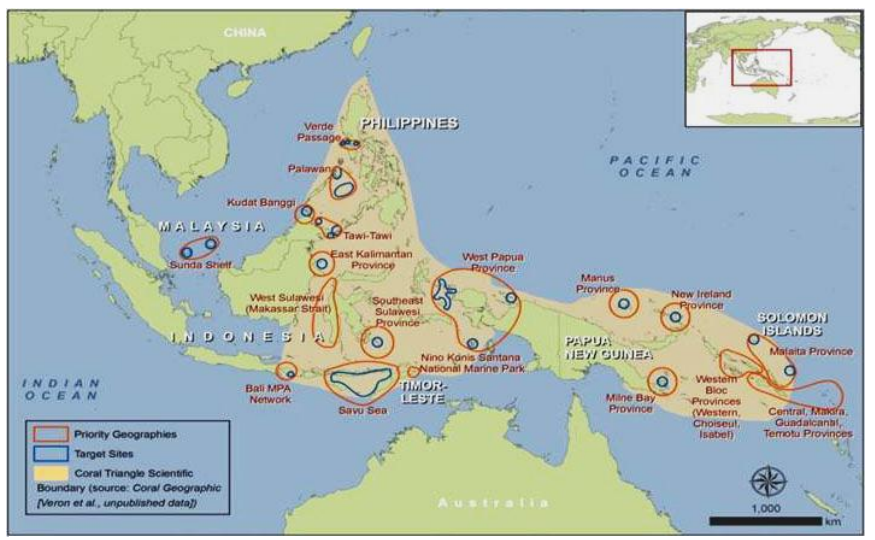

Figure 1. Map of the Coral Triangle, highlighting priority areas (Anon., n.d.)

\section{Menjangan Island and the Waters Adjacent to Bali Barat National Park (BBNP)}

Menjangan Island lies $0.8 \mathrm{~km}$ off the northwest coast of Bali (Fig. 2) and is sacred to the Hindus of Bali and Eastern Java. It has no permanent inhabitants, but contains four temples (Taman Kelenting

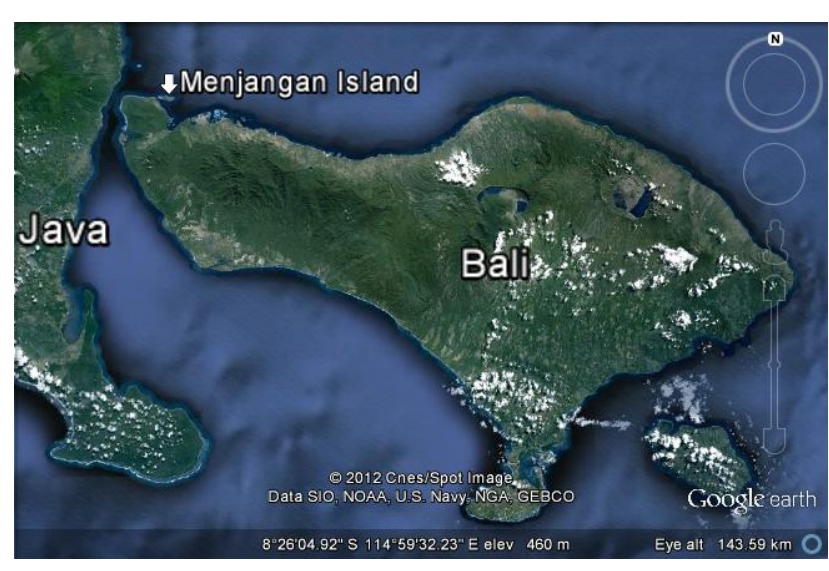

Figure 2.Map of Menjangan Island in relation to Bali.
Sari, Pesraman Kebo Iwa, Pendopo Agung Dalem Patih Gadjah Mada and Segara Giri), to which the Balinese take boats from the mainland to pray and make offerings. It is also part of Taman Nasional Bali Barat (Bali Barat National Park, BBNP), which evolved from the Suaka Margasatwa Bali Barat (Bali Barat Wildlife Reserve) established in 1947. Menjangan Island was added to this reserve in 1978 (Polunin et al., 1983) and in 1984 became one of Indonesia's first MPAs.

BBNP is surrounded by six villages, which are governed by the Balinese districts of Buleleng with its capital at the city of Singaraja, and Jembrana with its capital at Negara. This

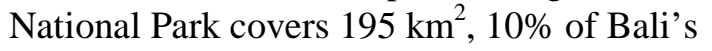


landmass. Its terrestrial habitats include primary monsoon forest, $3.1 \mathrm{~km}^{2}$ of mangrove forest, lowland rainforest, and savannah. Its marine habitats comprise $0.4 \mathrm{~km}^{2}$ of seagrass habitat, $8 \mathrm{~km}^{2}$ of coral reef (comprising $4.3 \mathrm{~km}^{2}$ of reef flat and $3.8 \mathrm{~km}^{2}$ of reef-edge), $22 \mathrm{~km}^{2}$ of shallow continental shelf $(<50 \mathrm{~m}$ depth), $2.6 \mathrm{~km}^{2}$ of deep-water continental shelf (50-200 m depth), and $0.2 \mathrm{~km}^{2}$ of continental slope (>200 $\mathrm{m}$ depth).

The Ministry of Forestry in Jakarta, according to Law No 5/1990 concerning Conservation of Natural Resources, manages BBNP. This law reiterates that the state owns the land and other natural resources (hakmenguasainegara) as written in the Constitution (article 33; Putra and Widyastuti, 1999). All foreign visitors to the park pay an entrance fee of IDR 20,000 per day (approximately US\$2) and domestic tourists pay IDR 2,000. An official guide accompanies all tourists who enter the park. This fee goes directly to the Ministry of Forestry's headquarters in Jakarta.

Since 2002, sixteen coral reef sites along the northwest of Bali (Fig. 3) have been monitored by a consortium of international groups including: Wildlife Conservation Society, Indonesia (WCS) in 2002 and 2009, Reef Check Indonesia Foundation with WCS in 2009, and the Reef Check Indonesia Foundation in 2010 and 2011 (Stuart Campbell and Jensi Sartin pers. comm.).With the exception of a team from The National Museum of Natural History (Netherlands) and WWF Netherlands (Hoeksema and Putra, 2000), no other data was published. Thus, this paper summarizes what is known for this area and reports on a 2011 study while making comparisons with data from the WCS 2002 study.

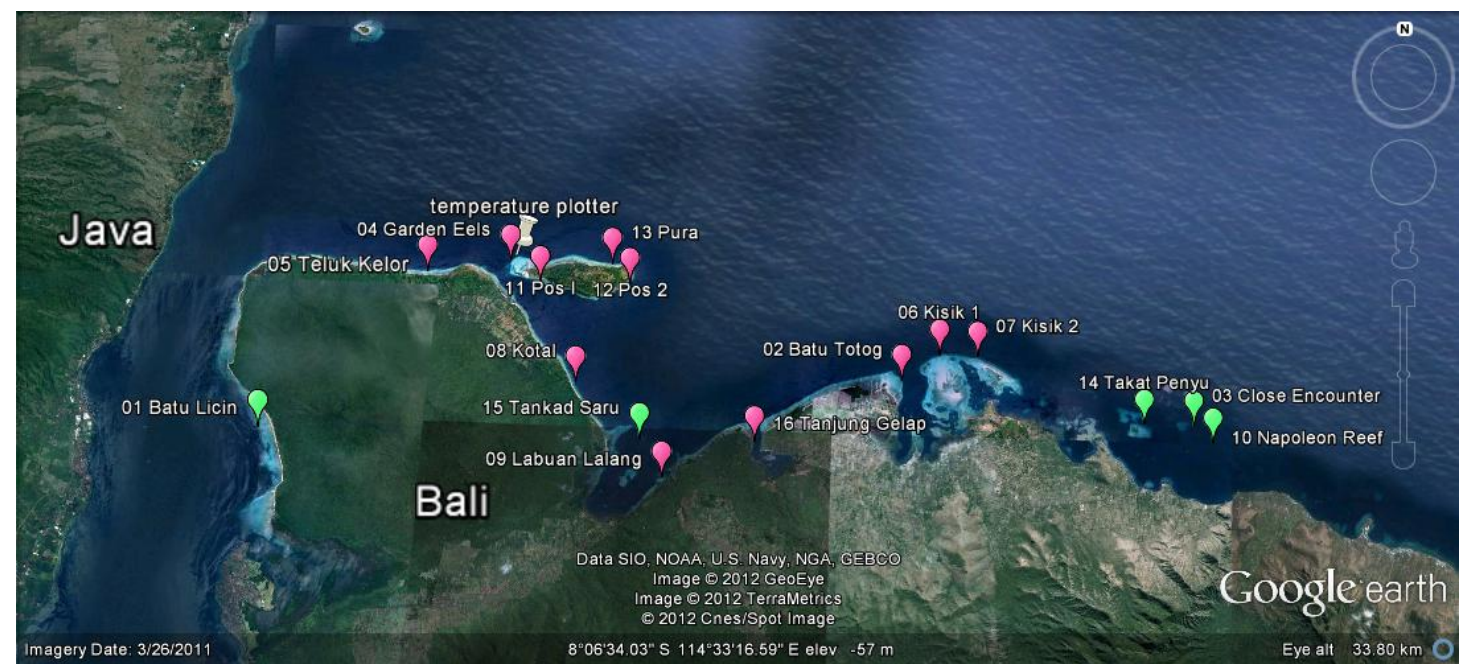

Figure 3. The 16 sites in Northwest Bali surveyed since 2002. Eleven of these sites were monitored in 2011 and are labeled pink. Those areas marked with green labels were not included in the 2011 study and are not part of this study.

The sixteen sites were chosen to represent four geographical areas: Pemuteran, Sumber Kima, BBNP Menjangan Is., and BBNP Sumber Klampok (Table 1). BBNP Menjangan Is. defines the area that is located within BBNP, where no fishing is permitted and there is no human habitation. BBNP Sumber Klampok is an area within BBNP where fishing is prohibited, but it is near to human habitation. Three of the sixteen sites are located in the town of Pemuteran, an area that is managed by a Community MPA initiative with no fishing allowed and three are located by the town of Sumber Kima, which is an area with open access to all fishermen. 
Table 1.Identification of the 16 sites. Sites shaded with pink were surveyed in 2011 and 2002. Sites shaded with green were only surveyed in 2002.

\begin{tabular}{|c|c|c|c|c|c|}
\hline $\begin{array}{l}\text { Site } \\
\text { Code }\end{array}$ & Site Name & Village & Area Status & Latitude S & Longitude E \\
\hline 01 & Batu Licin & Bali Mainland & BBNP MPA & $8^{\circ} 7^{\prime} 59.81 "$ & $\begin{array}{l}114^{\circ} 26^{\prime} \\
23.06^{\prime \prime}\end{array}$ \\
\hline 02 & Batu Togog & Sumber Kima & Open Access & $8^{\circ} 7^{\prime} 06.78 "$ & $114^{\circ} 35^{\prime} 42.88^{\prime \prime}$ \\
\hline 03 & $\begin{array}{l}\text { Close } \\
\text { Encounter }\end{array}$ & Pemuteran & $\begin{array}{l}\text { Community } \\
\text { MPA }\end{array}$ & $8^{\circ} 7^{\prime} 41.43^{\prime \prime}$ & $\begin{array}{l}114^{\circ} 40^{\prime} \\
10.57^{\prime \prime}\end{array}$ \\
\hline 04 & Garden Eels & $\begin{array}{l}\text { BBNP Menjangan } \\
\text { Is. }\end{array}$ & BBNP MPA & $8^{\circ} 5^{\prime} 31.38 "$ & $\begin{array}{l}114^{\circ} 29^{\prime} \\
54.25^{\prime \prime}\end{array}$ \\
\hline 05 & Teluk Kelor & $\begin{array}{l}\text { BBNP Menjangan } \\
\text { Is. }\end{array}$ & BBNP MPA & $8^{\circ} 5^{\prime} 42.41^{\prime \prime}$ & $\begin{array}{l}114^{\circ} 28^{\prime} \\
42.88^{\prime \prime}\end{array}$ \\
\hline 06 & Kisik 1 & Sumber Kima & Open Access & $8^{\circ} 6^{\prime} 43.56^{\prime \prime}$ & $\begin{array}{l}114^{\circ} 36^{\prime} \\
16.84^{\prime \prime} \\
\end{array}$ \\
\hline 07 & Kisik 2 & Sumber Kima & Open Access & $8^{\circ} 6^{\prime} 44.65^{\prime \prime}$ & $\begin{array}{l}114^{\circ} 36^{\prime} \\
51.26^{\prime \prime} \\
\end{array}$ \\
\hline 08 & Kotal & Sumber Klampok & BBNP MPA & $8^{\circ} 7^{\prime} 15.53 "$ & $\begin{array}{l}114^{\circ} 30^{\prime} \\
54.00^{\prime \prime} \\
\end{array}$ \\
\hline 09 & Labuan Lalang & Sumber Klampok & BBNP MPA & $8^{\circ} 8^{\prime} 36.49^{\prime \prime}$ & $\begin{array}{l}114^{\circ} 32^{\prime} \\
11.47^{\prime \prime}\end{array}$ \\
\hline 10 & Napoleon Reef & Pemuteran & $\begin{array}{l}\text { Community } \\
\text { MPA }\end{array}$ & $8^{\circ} 7^{\prime} 56.40^{\prime \prime}$ & $\begin{array}{l}114^{\circ} 40^{\prime} \\
28.48^{\prime \prime}\end{array}$ \\
\hline 11 & Pos I & $\begin{array}{l}\text { BBNP Menjangan } \\
\text { Is. }\end{array}$ & BBNP MPA & $8^{\circ} 5^{\prime} 49.36^{\prime \prime}$ & $\begin{array}{l}114^{\circ} 30^{\prime} \\
20.66^{\prime \prime}\end{array}$ \\
\hline 12 & Pos II & $\begin{array}{l}\text { BBNP Menjangan } \\
\text { Is. }\end{array}$ & BBNP MPA & $8^{\circ} 5^{\prime} 48.53^{\prime \prime}$ & $\begin{array}{l}114^{\circ} 31^{\prime} \\
39.10^{\prime \prime} \\
\end{array}$ \\
\hline 13 & Pura & $\begin{array}{l}\text { BBNP Menjangan } \\
\text { Is. }\end{array}$ & BBNP MPA & $8^{\circ} 5^{\prime} 31.40^{\prime \prime}$ & $\begin{array}{l}114^{\circ} 31^{\prime} \\
23.28^{\prime \prime} \\
\end{array}$ \\
\hline 14 & Takat Penyu & Pemuteran & $\begin{array}{l}\text { Community } \\
\text { MPA }\end{array}$ & $8^{\circ} 7^{\prime} 41.26^{\prime \prime}$ & $\begin{array}{l}114^{\circ} 39^{\prime} \\
24.67^{\prime \prime}\end{array}$ \\
\hline 15 & Tankad Saru & Sumber Klampok & BBNP MPA & $8^{\circ} 8^{\prime} 03.50^{\prime \prime}$ & $\begin{array}{l}114^{\circ} 31^{\prime} \\
51.11^{\prime \prime}\end{array}$ \\
\hline 16 & Tanjung Gelap & $\begin{array}{l}\text { BBNP Menjangan } \\
\text { Is. }\end{array}$ & BBNP MPA & $8^{\circ} 8^{\prime} 03.98 "$ & $\begin{array}{l}114^{\circ} 33^{\prime} \\
32.40^{\prime \prime}\end{array}$ \\
\hline
\end{tabular}

\section{MATERIALS \& METHODS}

In 2002 and 2011, surveys were conducted during the NW monsoon season; in January 2002; and in March- April 2011. For each of the three management areas (Sumber Kima = three sites; BBNP Menjangan Is. = six sites; BBNP Sumber Klampok = two sites), mean $( \pm S E)$ values are presented for coral cover, number of coral genera, live coral damage, and number of fishing gears in 2002 and 2011. Mean $( \pm$ SE) values for each management area are presented for reef fish in 2011.

\section{Data Collection}

Coral Cover A Point Intercept Transect (PIT) was used to record the composition of benthic substrate. Along three $50 \mathrm{~m}$ transects at two depths $(2-4$ and 6-8 $\mathrm{m})(\mathrm{n}=6)$ the substrate at the point under the transect was recorded at intervals of $50 \mathrm{~cm}$. The substrate was described in one of 16 benthic categories; however, live hard coral cover is presented here. The mean coral cover $(\% \pm \mathrm{SE})$ of each of the three management areas is presented for 2002 and 2011. 
Coral Genera. Counts of hard live coral colonies were recorded to genus level along three transects at each site and at two depths (2-4 $\mathrm{m}$ and 6-8 $\mathrm{m}),(\mathrm{n}=6)$. The mean number of coral colonies (no. \pm SE) of each of the three management areas is presented for 2002 and 2011.

Coral Damage. Damage to live coral colonies was recorded along three 2 x $50 \mathrm{~m}$ belt transects. In 2011 the number of colonies showing signs of damage were counted and recorded into four categories; broken, bleached, diseased, and eaten by Acanthaster planci. In 2002 corals showing signs of physical damage due to breakage were recorded. The mean proportion of coral colonies ( $\% \pm \mathrm{SE}$ ) showing signs of breakage in each of the three management areas is presented for 2002 and 2011. The mean number of coral colonies (no. $100 \mathrm{~m}^{2} \pm \mathrm{SE}$ ) showing signs of damage due to bleaching, disease, and by physical means (e.g. broken by anchors) in each of the three management areas is presented for 2011.

Fishing Gear. Fishing gears, including all lines, nets and traps, were counted along three 2 x $50 \mathrm{~m}$ $\left(100 \mathrm{~m}^{2}\right)$ belt transects in 2002 and 2011 . The mean number of fishing gears (no. $100^{2} \pm \mathrm{SE}$ ) in each of the three management areas is presented for 2002 and 2011.

Reef Fish. Species-level surveys of all non-cryptic fishes (45 families) were conducted using underwater visual census along three $50 \mathrm{~m}$ belt transects at each depth and at each site. All fish greater than $10 \mathrm{~cm}$ total length (TL) in a $5 \mathrm{~m}$ wide belt were recorded, and all fish less than $10 \mathrm{~cm}$ TL were recorded in a $2 \mathrm{~m}$ wide belt. To account for differences in transect widths ( 2 or $5 \mathrm{~m}$ ) fish densities were standardized to individuals per hectare, and converted to biomass using published length-weight relationships for each species, following Hoey and Bellwood (2009). Mean $( \pm$ SE) reef fish biomass (kg $\mathrm{ha}^{-1}$ ), density (no. ha ${ }^{-1}$ ), and number of fish species (no. $250 \mathrm{~m}^{2}$ ) in each of the three management areas is presented for 2011 - 2012.

Seawater Temperature 2010-2011. Seawater Temperature was monitored from March 8, 2010 to March 12 and 22, 2011, and March 30, 2011 to June 2, 2012 at the Northwest Corner of Menjangan Island (Latitude S $08^{\circ}$ 05.458' and Longitude E $114^{\circ}$ 29.983', Fig. 3). Data loggers (Onset Hobo Temps) recorded temperatures at two hour intervals at depths of $3 \mathrm{~m}, 14 \mathrm{~m}$, and $17.5 \mathrm{~m}$ in 2010-2011 and 3m and $14 \mathrm{~m}$ at 4 hour intervals 2011-2012.

\section{Statistical Analyses}

Variation in the cover of live coral, number of coral genera, coral damage and number of fishing gears, was compared among years (two levels; 2002, 2011) and management areas (levels; Sumber Kima, BNP Menjangan Is.; BBNP Sumber Klampok) using a 2-factor ANOVA. Variation in the biomass, density and number of fish species in 2011 were compared among management areas (three levels; Sumber Kima, BNP Menjangan Is.; BBNP Sumber Klampok) using a single factor ANOVA. Year and management area were fixed orthogonal factors. Assumptions of the ANOVA were examined by residual analysis and no data transformation was required.

\section{RESULTS}

\section{Coral Cover}

Overall, mean coral cover varied from 15.9-28.1\% and 28.3-31.1\% in 2002 and 2011 respectively. Coral cover increased significantly $\left(F_{1,15}=6.60, p=0.021\right)$, from 2002 to 2011 across all management zones, but no differences in coral cover were found among management zones $\left(\mathrm{F}_{2,15}=3.24\right.$, $\mathrm{p}=0.068)$, (Fig.4). 


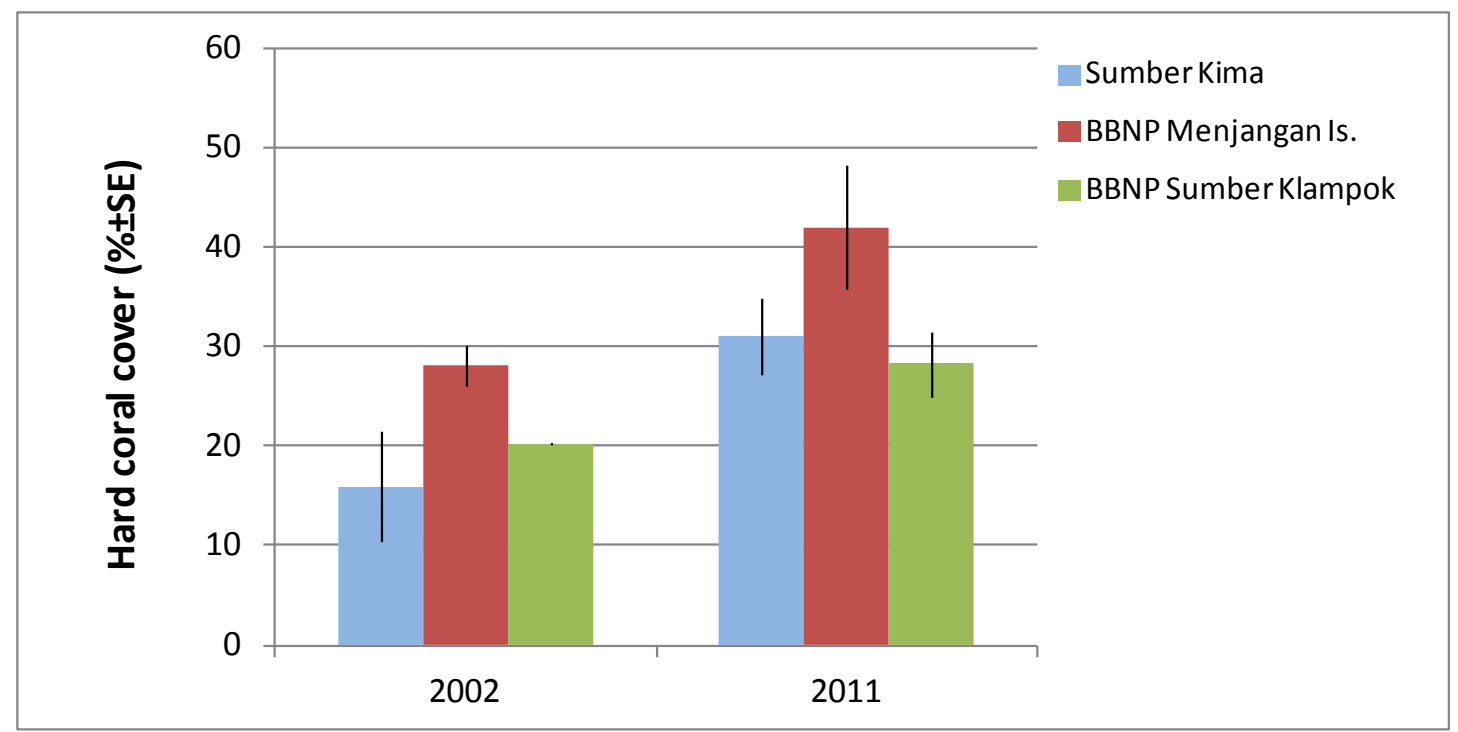

Figure 4. Live hard coral cover in 2002 and 2011 in three management areas.

\section{Hard Coral Genera}

The mean number of coral genera varied from 15.0-24.6 and 5.6-7.6 in 2002 and 2011 respectively. The number of coral genera cover decreased significantly $\left(F_{1,15}=29.3, p<0.001\right)$, from 2002 to 2011 across all management zones (Fig. 5). No significant differences in the number of hard coral genera were found statistically between management zones $\left(\mathrm{F}_{2,15}=0.68, \mathrm{p}=0.52\right)$, although the graph shows variation (Fig.5).

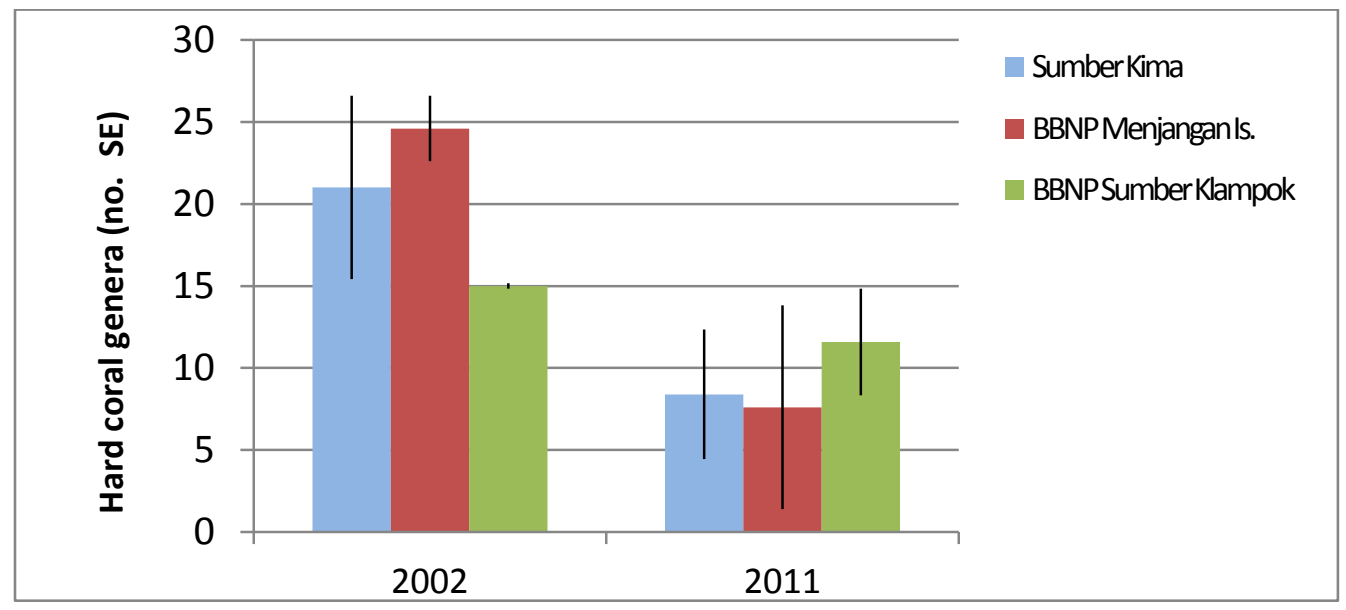

Figure 5. Number of coral genera in three management areas in 2002 and 2011.

\section{Broken Corals}

Overall, the proportion of broken corals varied from 0.08-13.1\% and 9.0-20.0\% in 2002 and 2011 respectively. Broken coral cover increased significantly $\left(\mathrm{F}_{1,15}=4.70, \mathrm{p}=0.046\right)$ from 2002 to 2011 across all management zones, but no statistically significant differences in the proportion of broken corals was 
found between management zones $\left(F_{2,15}=0.84, p=0.450\right)$, (Fig.6). However figure 6 shows Sumber Kima had much more damage in 2002 than the other sites and Sumber Klampok had hardly any broken coral.

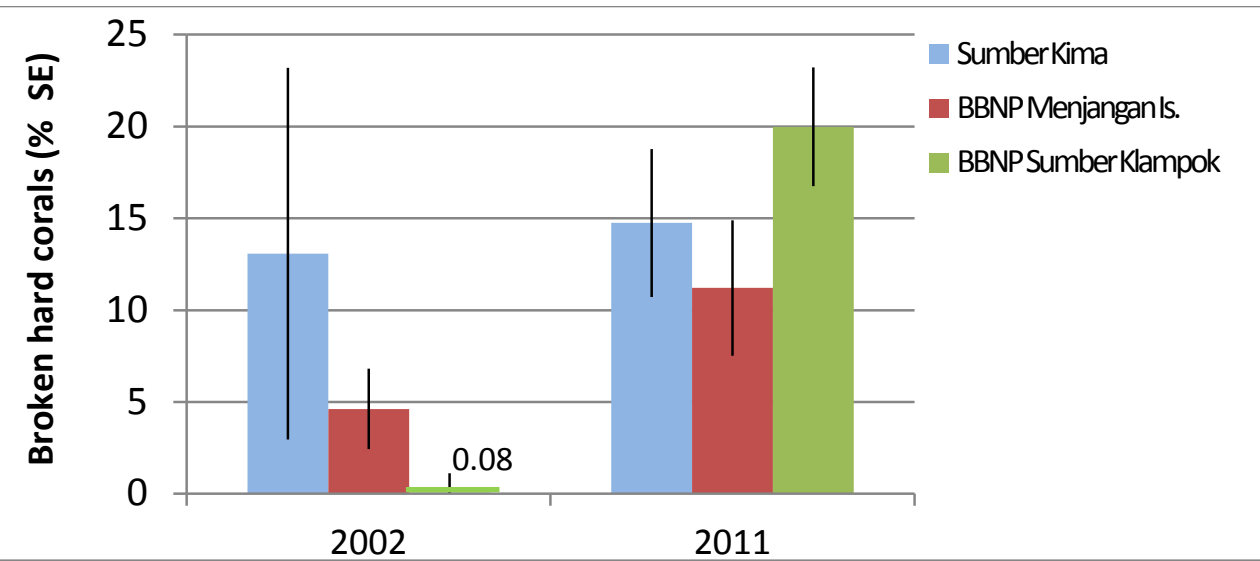

Figure 6. Proportion of broken corals in 2002 and 2011 in three management areas.

\section{Fishing Gears}

The mean number of fishing gears per $100 \mathrm{~m}^{2}$ varied from 0.38-0.61 and 0.03-0.17 in 2002 and 2011 respectively. Fishing gears decreased significantly $\left(\mathrm{F}_{1,15}=6.60, \mathrm{p}=0.021\right)$ from 2002 to 2011 across all management zones, with the rate of change varying among zones (Fig.7). No statistically significant difference in the number of fishing gears was found between management zones $\left(\mathrm{F}_{2,15}=1.28, \mathrm{p}=0.307\right)$ (Fig.7).

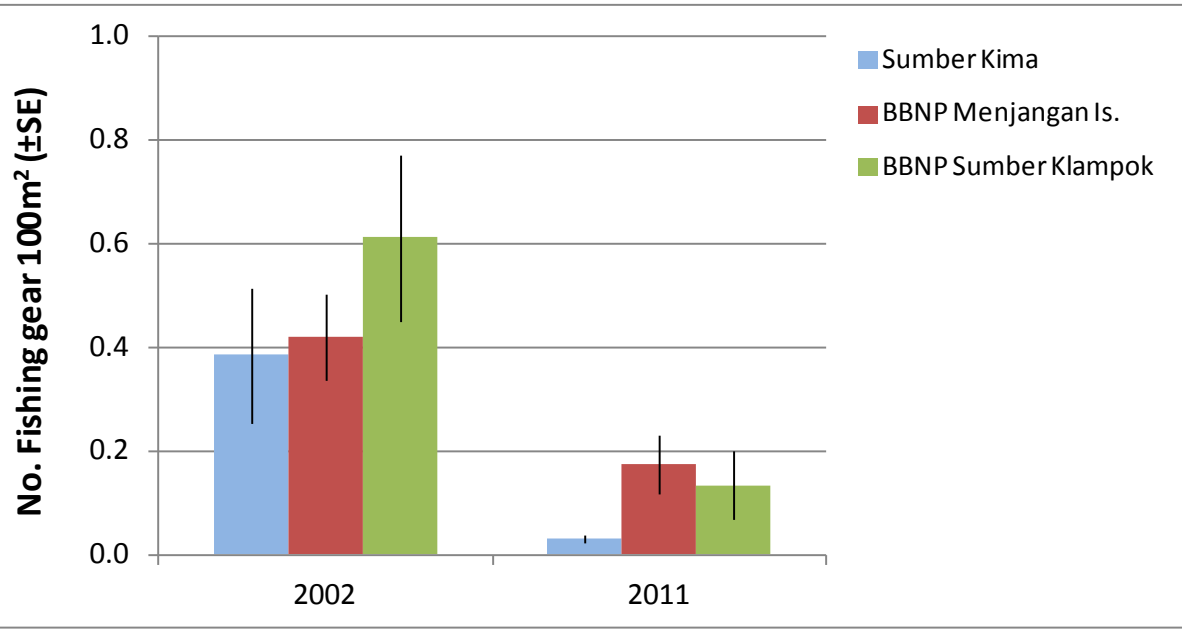

Figure 7. Number of fishing gears per $100 \mathrm{~m}^{2}$ in 2002 and 2011 in three management areas. 


\section{Coral Damage}

In 2011, the mean number of colonies damaged by bleaching varied from 1.8-2.6, the number of corals damaged by disease varied from 2.9-6.6, while the number damaged by recent physical means varied from 5.1-18.0 (Fig. 8).

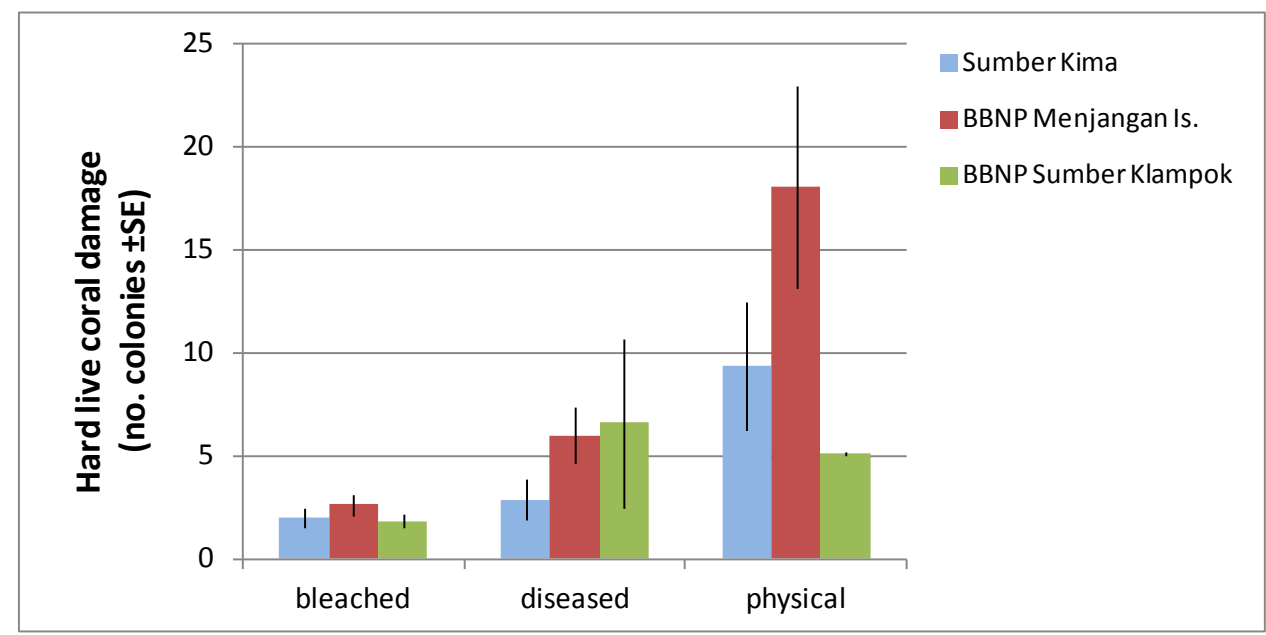

Figure 8. Number of hard coral colonies damaged by bleaching, disease and physical means in three management areas in 2011.

\section{Fish Biomass}

In 2011, the mean biomass of reef fishes was higher in both BBNP locations (Menjangan Is. Mean= 594.4 \pm 104.6SE; Sumber Klampok mean $=601.3 \pm 96.2 \mathrm{SE} \mathrm{kg} \mathrm{ha}{ }^{-1}$ ) than at Sumber Kima (mean $=245.2 \pm 31.6 \mathrm{SE}$ ). Although the mean biomass inside the BBNP was double, the differences were not statistically significant $\left(\mathrm{F}_{2,8}=3.05, \mathrm{p}=0.104\right)$ (Fig.9).

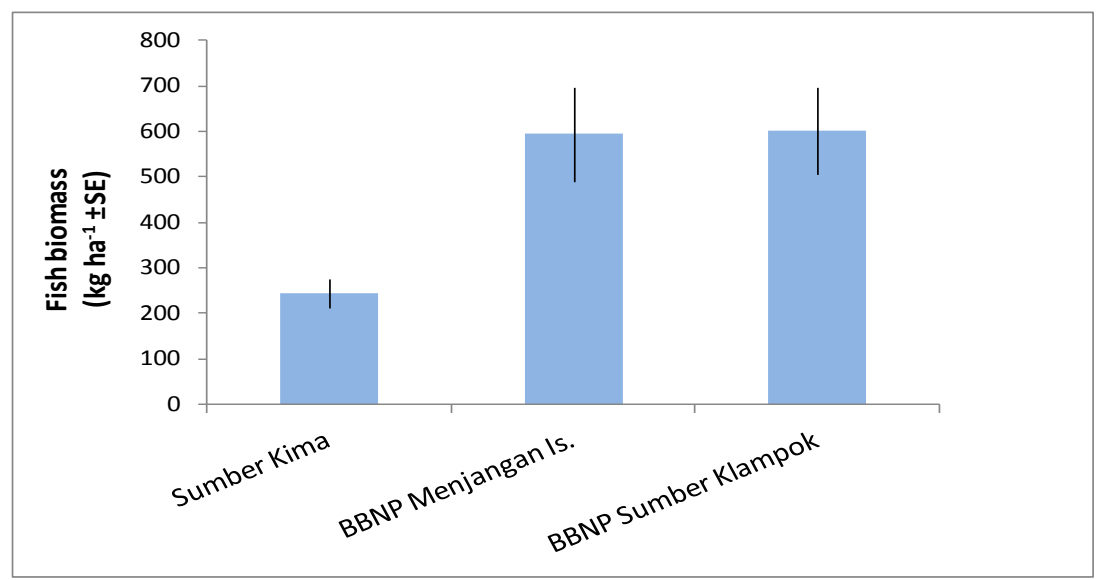

Figure 9. Reef fish biomass in three management areas in 2011. 


\section{Fish Density}

In 2011, the mean density of reef fishes was significantly higher at BBNP Menjangan Is. (mean = $36351 \pm 5327 \mathrm{SE})$ than at Sumber Kima (mean $=12466 \pm 4812 \mathrm{SE}),\left(\mathrm{F}_{2,8}=4.51, \mathrm{p}=0.048\right)$. Fish density at BBBNP Sumber Klampok $($ mean $=26565 \pm 3635 S E)$ did not differ with the other 2 sites (Fig.10).

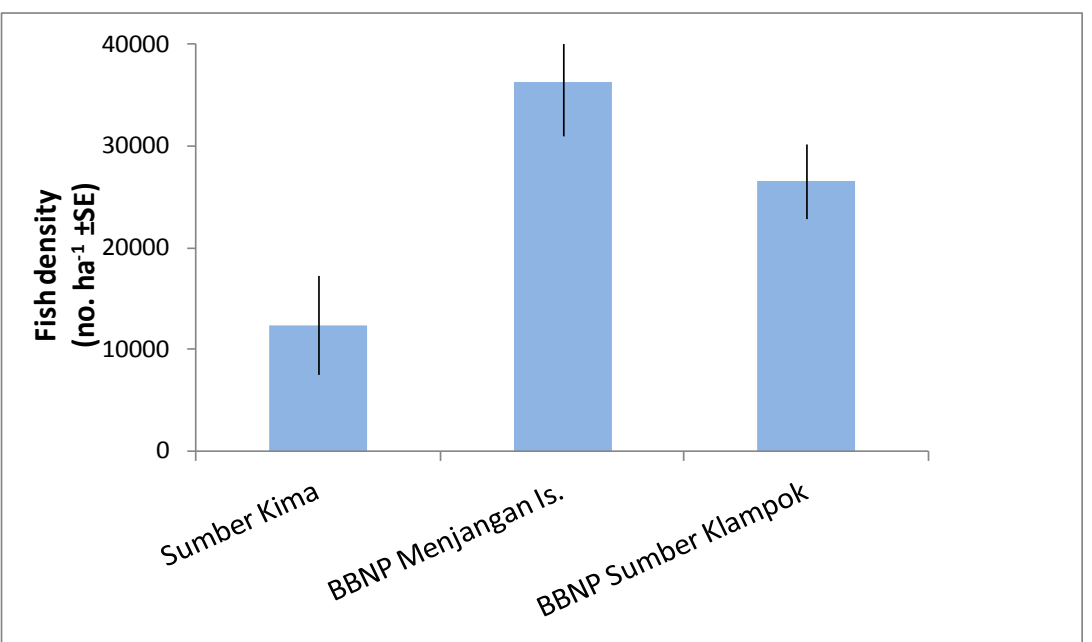

Figure 10. Reef fish density in three management areas in 2011.

\section{Number of Fish Species}

In 2011, the mean number of fish species was significantly higher in BBNP Sumber Klampok (mean = $66.8 \pm 1.3 \mathrm{SE}$ ) than at BBNP Menjangan Is. (mean $=54.4 \pm 3.1 \mathrm{SE}$ ), which in turn was higher than at Sumber Kima (mean $=33.4 \pm 5.9 S E)\left(F_{2,8}=11.8, \mathrm{p}=0.004\right)($ Fig.11).

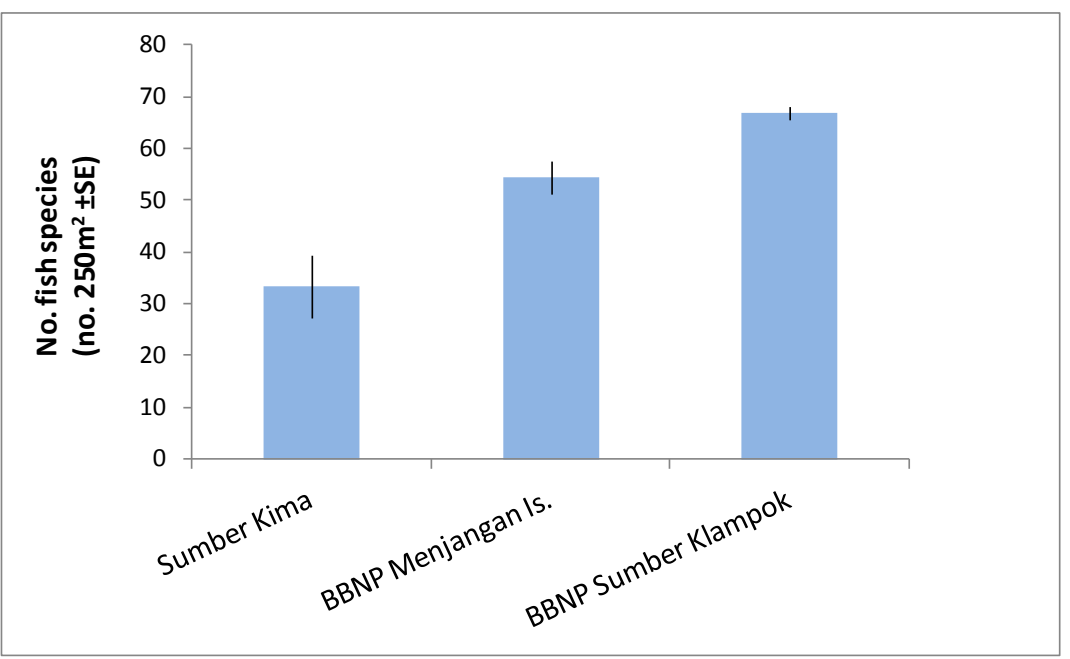

Figure 11. Number of reef fish species in 3 management areas in 2011. 
The Index of Fish Diversity. The Index of Fish Diversity in the Indo Pacific region (CFDI; Allen and Werner, 2002) was used to understand the species richness of the six most common fish families (Acanthuridae, Chaetodontidae, Labridae, Pomacanthidae, Pomacentridae and Scaridae; Table 2). The fish species richness observed in the BBNP Menjangan Is. and BBNP Sumber Klampok regions were "moderate" as compared to "Sumber Kima," the region outside the restricted area, which was poor.

Table 2. Index of Fish Diversity for six common families in NW Bali.

\begin{tabular}{|l|l|l|l|l|l|}
\hline Village area & $\begin{array}{l}\text { Number } \\
\text { of sites }\end{array}$ & $\begin{array}{l}\text { Mean } \\
\text { sp. } \\
\text { CFDI }\end{array}$ & $\begin{array}{l}\text { Max } \\
\text { CFDI for } \\
\text { a site }\end{array}$ & $\begin{array}{l}\text { Min } \\
\text { CFDI for } \\
\text { a site }\end{array}$ & $\begin{array}{l}\text { CFDI } \\
\text { category }\end{array}$ \\
\hline Sumber Kima & 3 & 50 & 63 & 37 & Poor \\
\hline BBNP Menjangan Is. & 6 & 73 & 80 & 62 & Moderate \\
\hline BBNP Sumber Klampok & 2 & 86 & 87 & 84 & Moderate \\
\hline
\end{tabular}

\section{Seawater Temperature}

Temperature monitoring at 3,14, and $17.5 \mathrm{~m}$ was met with partial success. The logger at $3 \mathrm{~m}$ failed during 2010-2011, while two loggers, which were deployed at $3 \mathrm{~m}$ and $14 \mathrm{~m}$, functioned during 20112012. The $14 \mathrm{~m}$ site yielded a continuous two year record (Table 3, Fig. 12). Summary statistics of the temperature revealed that on average the shallows were slightly warmer than the deeper site. Maximum temperature at $3 \mathrm{~m}$ was $0.8^{\circ} \mathrm{C}$ warmer than the $14 \mathrm{~m}$ site. A comparison of $14 \mathrm{~m}$ and $17.5 \mathrm{~m}$ temperature for 2010-2011 with $14 \mathrm{~m}$ data from 2011-2012 suggests 2010-2011 was slightly warmer than 2011-2012.

Table 3. Summary of seawater temperatures recorded at Menjangan Island.

\begin{tabular}{|l|c|c|c|c|}
\hline & $3 \mathrm{~m}(2011-12)$ & $14 \mathrm{~m}(2011-12)$ & $14 \mathrm{~m}(2010-11)$ & $\begin{array}{l}17.5 \mathrm{~m}(2010- \\
11)\end{array}$ \\
\hline Mean & 28.4 & 28.0 & 28.6 & 28.5 \\
\hline Std. & 1.0 & 0.9 & 0.9 & 0.9 \\
\hline Max & 31.1 & 30.3 & 30.7 & 30.7 \\
\hline Min & 26.0 & 26.0 & 26.0 & 25.6 \\
\hline
\end{tabular}




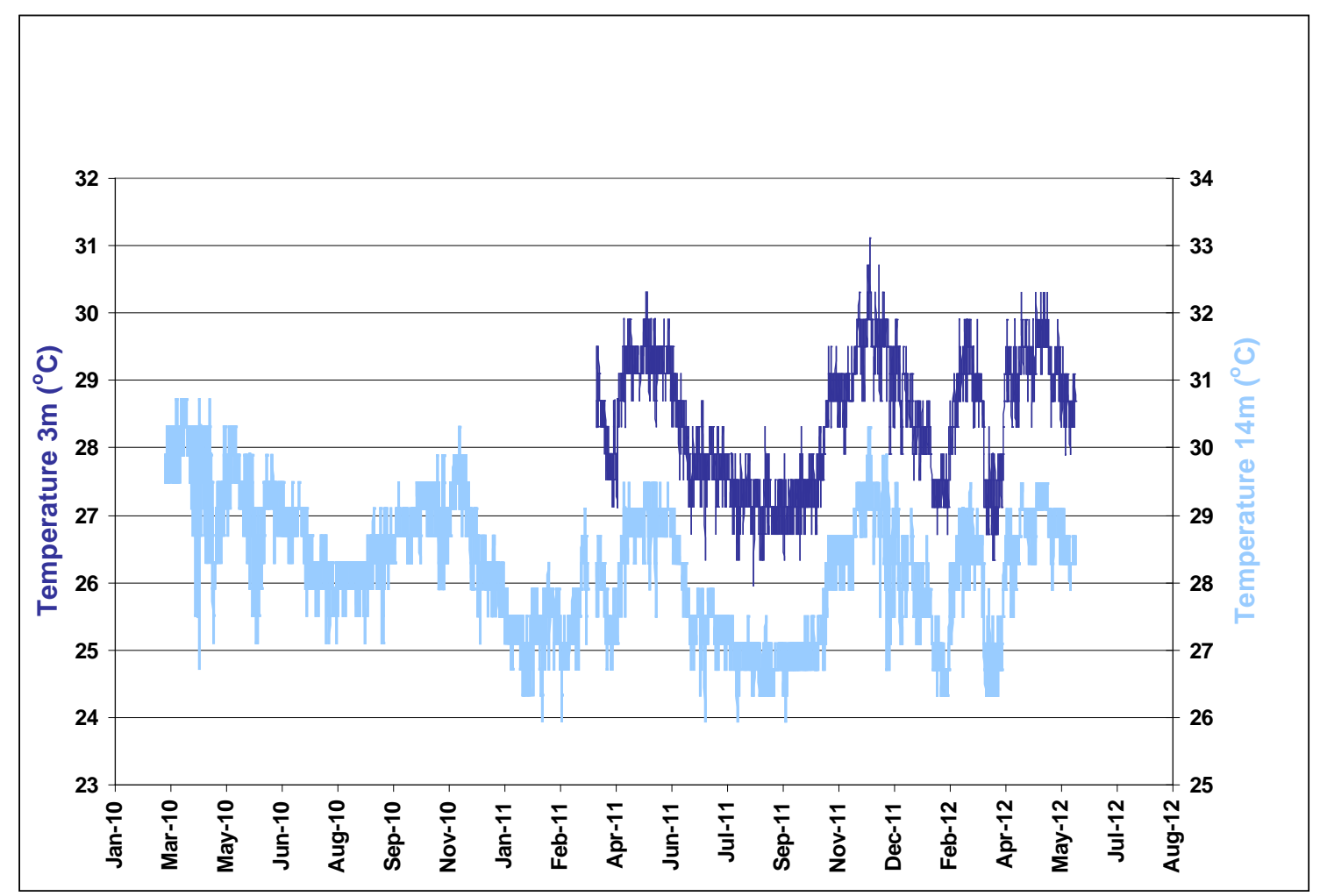

Figure 12. Seawater temperatures at Menjangan Island (March 2010 to June 2012) 3 m and $14 \mathrm{~m}$.

The sensors show that there were two warming peaks in 2010-2011 and four in 2011-2012. Sharp decreases in temperature, probably driven by localized upwelling events, occurred throughout the year. The pronounced lower temperatures in February and April 2012 coincide with statements made by the local divers about unusually large storms that occurred at that time. The recordings also show temperature drops at the deeper depth and occasionally warmer spikes at the $14 \mathrm{~m}$ depth. Such data suggest that cooler, deeper water moves up into the shallows while warmer, surface waters may be mixed down into the water column. These interpretations were supported by our experiences with temperature shifts while diving during March 2010 and March-April 2011. Menjangan Island is surrounded by relatively deep water and is close to the northern end of the Bali Strait between the islands of Bali and Java with a width of $2.4 \mathrm{~km}$ (Fig.3). Current velocities in these narrow straits can run as high as 6-7 knots.

\section{DISCUSSION}

\section{Summary of Results}

Overall the data show an increase from 2002 to 2011 in live coral cover across all sites and both inside and outside Bali Barat National Park (Fig. 4). This indicates recovery of the coral from the bleaching event damage in 1997 observed by Hoeksema and Putra (2000) in West Bali, which co-insides with the 1997-1998 El Nino event, known to have impacted many coral reefs.

Why BBNP Menjangan Is. has fewer coral genera than either of the other sites is an enigma (Fig. 5). Logically BBNP Menjangan Is. should have more coral genera since it is not subject to human habitation and development like the other two sites. Thus, possible explanations for this finding could include: (1) BBNP Menjangan Is. was hit harder by the 1998 event than surrounding areas and lost more 
coral genera; (2) because Menjangan Is. is an offshore habitat as compared to the other two coastal sites, differences in habitat may favor a reduced biodiversity; and (3) more live coral cover may decrease the number of coral genera overall due to competition for space.

Physical damage to corals increased from 2002 to 2011 across all areas and most notably at BBNP Sumber Klampok and Sumber Kima (Fig. 6).There are fishing boats in the region that still use destructive fishing techniques (cyanide and dynamite). Dynamite explosions were heard underwater by the authors in 2011 and they observed boats in Sumber Kima with divers and hookah rigs suggesting cyanide fishing. Additionally it is possible that the higher amount of dead coral recorded at BBNP Sumber Klampok may be due to the high levels of terrestrial organic sediment which was observed coating the reef (these sites are near the Labuan Lalang Harbor). Finally, because there is more live coral cover in 2011 than in 2002, there is more live coral available to be damaged by physical factors, both natural and human.

Figure 6 and 8 also demonstrate that BBNP Menjangan Is. live coral damage is increasing. Our team observed numerous small boats anchoring on the reef repeatedly during 2010, 2011 and 2012. There are many more boats arriving at the shores of BBNP Menjangan Is. than at the other two sites because daily visitors come to the temples to pray or to dive, and they often anchor when moorings are not available. The decrease in fishing gears (Fig. 7) found in 2011 is consistent with the increase in coral cover observed because fishing pressure not only reduces fish biomass, but increases damage to coral by physical mechanisms and ecological change.

Fish abundance, biomass, and biodiversity were lowest at Sumber Kima, which is a destination for the local fishermen (Fig. 9 and 10). Sumber Kima is particularly known as an area where fish are collected for the aquarium trade, a technique not requiring nets and thus suggesting why so few fishing gears were found on the reef there. Fishing gears (net and line/hook) data, however, suggests that artisanal fishing intensity (Fig. 7) is evenly distributed in all areas and that until the BBNP no-take zones are enforced, fishing will continue within the MPA and fish diversity will undoubtedly remain moderate or decline further.

\section{Threats to Menjangan Island's Coral Reef}

Reefs in all the tropical seas are threatened by degraded ecological conditions that originate locally, regionally, and from the shores of distant continents (Bryant et. al., 1998; Hatziolos et. al 1998). Some of the increased stresses are amplifications of naturally occurring stress (temperature and $\mathrm{pH}$ change) while others are anthropogenic (harvesting, sedimentation and anchor damage). While all reefs are affected by global change such as elevated ocean temperatures, ocean acidification and increased ultraviolet light, coastal reefs near population centers are exposed to even more pressures from sewage, watershed effluent, garbage dumping, and greatly increased levels of harvesting.

Thus the stress to reefs resides within a series of nested scales making it extremely difficult to tease apart the individual contribution of each stressor. Furthermore, the impacts appear to be cumulative and possibly synergistic. Thus the removal of stress at any level will benefit coral conservation by helping to improve the resiliency of corals to other stressors.

The three regions we have surveyed vary with respect to exposure to a variety of stressors. Fishing pressures appear greatest at Sumba Kima, while land based sources of pollution and water temperature increases seem to have greatly impacted BBNP Sumber Klampok, where diseases seem to be more prevalent in areas close to centers of human habitation as the reef offshore Labuan Lalang (Site 09). Menjangan Island is somewhat removed from land sediments and protected from heavy fishing pressures.

Inadequate Mooring Buoys. There are eight permanent moorings located at the most popular dive sites around Menjangan Island. "International Moorings" installed 7 of these in 1994. In 2011, six of these were still intact and provided secure mooring options for diving boats but other cement block moorings that were later installed were pulled off the reef when up to 50 boats tried to tie onto these moorings during peak tourist season. Thus, in the absence of an underwater drill, new mooring buoys are 
now made by securing rope (protected with plastic or fire hose) around the base of large reef areas that have suitable holes to tie the rope without damage to the corals above.

In addition to the fact that there are not enough mooring buoys for the number of boats arriving at Menjangan Island's shores, a secondary problem arises when the buoys and their lines fail or are taken for other purposes by visiting fishermen. Throughout the year, mooring buoys are decommissioned due to this problem and boats with anxious divers paying money end up resorting to anchoring. Thus, constant maintenance of the existing mooring buoys is required in addition to the installation of additional buoys to handle increased boat traffic.

Unenforced No-Take Zone. The coral reefs fringing Menjangan Island officially lie within a "notake" zone as well as within a "utilization zone" as defined by BBNP. Within the utilization zone, fishing for commercial purposes is prohibited but fishing for one's family is allowed. Obviously, this causes some uncertainty about who is allowed to fish and who is not and relies on good will of interpretation.

Many of the Balinese fishermen that previously fished the reef were encouraged to become boatdrivers for visitors and they, along with dive masters and snorkel guides, form the local community that observes what goes on at the island every day. They report that fishermen from the East coast of Java and Madura come to Menjangan Island because they have free access to the unpatrolled reefs. The authors also observed fishermen from Java illegally squid fishing in Banyuwedang Harbor (nearby Menjangan Island and within the BBNP utilization zone). Research in Banyuwangi in east Java revealed that communities there, that have been a key supplier to the ornamental fish trade for many decades (Polunin et al., 1983), were continuing to gain access to Menjangan Island for blast and cyanide fishing (Kartika, 2011; Kartarahardja, 2009).

Thus, aside from the good will of the local fishermen, fishing within the MPA is still active and persistent everywhere.

Destructive Fishing Practices. Many fishermen in Southeast Asia use explosives or potassium cyanide to stun fish, thereby enabling them to make large catches swiftly or select ornamental fish for the aquarium trade. Both blast fishing and cyanide fishing have been used for many years and are still in practice in NW Bali.

With blast fishing, the bombs are homemade, usually from fertilizer and fuses. The blast either kills the fish instantly or the shockwave stuns them. They float to the surface or fall to the reef bottom, but the underwater bomb also breaks up an area of coral reef substrate, creating a zone of rubble on which new corals cannot settle and grow. In the case of cyanide fishing, the fishermen use a small compressor onboard their boats to deliver air underwater through a piece of hose. They squirt a solution of potassium cyanide, readily available on a black market, or sometimes even household bleach, into corals and crevices on the reef to target a specific fish for the aquarium trade. The fish and those surrounding it are stunned and the target easily collected. If proving elusive, the fisherman will smash up a coral to reach the fish. The poison causes a bleaching effect on the corals it comes into contact with.

In 2011, the authors observed a number of boats in Sumber Kima with hookah rigs and divers in the water (suggesting cyanide fishing), but when approached they quickly left. Additionally, the authors of this paper witnessed blast fishing at Menjangan Island on $17^{\text {th }}$ and $20^{\text {th }} \mathrm{July}, 2009$ in daylight during peak tourist season and heard dynamite being used underwater while diving at Menjangan Island three times (May and June, 2012).

Both of these destructive fishing methods create an additional problem noticed in all areas off

NW Bali. Coral fragments created by a blast or broken by a cyanide fisherman break down into rubble. This is swept about by waves and currents and falls from the shallow reef downslope towards the deeper reef. As it cascades, it either smothers living coral or breaks it, causing more coral death and creation of more rubble. Since this flow remains unchecked, the falling rubble creates a stream of dead coral that creates caverns in the reef that, in turn, causes the reef along the sides of the troughs to slide inwards creating an even larger and growing gulley. In other words, the rubble begins the process of cutting away and eroding the reef. This is a significant source of ongoing destruction at BBNP Menjangan Is. and BBNP Sumber Klampok. Blast fishing is therefore destructive to coral reefs in both the short and long- 
term and is known to reduce resilience to natural perturbations such as climate change (McManus and Reyes, 1997).

Climate Change. Climate change is the greatest threat to coral reefs today because it causes abnormally high sea surface temperatures, which in turn may cause bleaching and possible death of an entire reef. In addition, climate change is bringing with it an increase of coral damage due to the increased acidification of seawater caused by absorption of atmospheric $\mathrm{CO}_{2}$ (Veron, 2008).

In the El Niño period of 1997-1998, every coral reef region in the world was affected by a mass bleaching event and 16\% of the world's coral reefs died (Spalding et al., 2001). Bleaching events due to elevated seawater temperature around Menjangan Island have since been observed in 2009, 2010 and 2011 (pers. comm.).

Trash and Plastics Pollution. There is no trash disposal system on Menjangan Island. Visitors (both Balinese coming to the temples for ceremonies and tourists) bring food and drink to the island and leave the wrappings behind. Additionally, Northwest ocean currents carry trash to its shores, and local tides from the Bali Strait bring trash dumped overboard from the ferries crossing between Bali and Java. While Menjangan Island suffers from this deluge of trash, so does the entire coast of Bali. Bali is in need of a better waste management system including adequate sanitary landfills and plastic recycling programs.

Harmful Species. There are two known outbreaks of harmful species in the vicinity of Menjangan Island, one in 1997 and one in 2009. We learned from local divers that in 1997, BBNP park rangers, dive operators and NGOs removed more than 700,000 Crown of Thorns sea stars (Acanthaster planci; Boekschoten, 2000).

In 2009, an infestation of a corallivorous snail, Drupellacornus, was causing significant coral damage at Pemuteran just a couple of miles to the east of Menjangan Island on Bali's north coast. The Jakarta Post stated that the Bio Rock Center had removed 26,374 snails from a single dive site between November 2008 and June 2009 (Kertaharja, 2009). Drupellacornus were present on the reefs of Menjangan Island in 2011.

Outbreaks such as these result in mass death of corals, which also contributes to creating more rubble. Thus, we are unable to determine with accuracy what percent of the reef has been damaged over time by destructive fishing, anchor damage or outbreaks of invertebrates on the reef.

Coastal Development. Menjangan Island lies opposite BBNP (where there is no development) and is $9 \mathrm{~km}$ from Java. Thus, it is not significantly affected by Javanese or Balinese coastal development. However, four temples have been constructed on the island over recent years, as well as a small ranger station, bathrooms and gazebos for shade, and in 2012 a fifth temple was being built. Much of the beach on the Southeast side and the coral reef on the Northeast side, of Menjangan Island have been used as building materials to build the temples and this practice continues today.

Low Level of Conservation Awareness. There is currently insufficient education about coral reef conservation taking place at Menjangan Island, both with the local communities who depend upon it for their livelihood and ceremonies as well as the tourists who come to visit. The authors observed divers standing on the corals in shallow waters, removing organisms from the reef as souvenirs and creating underwater graffiti including the carving of names into sponges.

Increasing Numbers of Visitors to the Island. Menjangan Island is a destination for Hindu worship as well as for overseas divers and snorkelers. Figure 13 shows the number of visitors to Menjangan Island from the years 2000 to 2010 and Figure 14 divides the number of 2010 visitors into activities. The graphs clearly show that the greatest number of visitors comes from the religious sector. Figure 13 shows that the overseas visitors reached a low in 2006 after the October 2002 and October 2005 Bali bombings. Numbers of overseas visitors have steadily increased since then and in 2010 were nearly at the level of 2002. Visitation by local people has also increased since 2006, probably because the 
economy is on the rise allowing them extra cash to pay for the trips to the island. It is also of interest to note the marked rise by local visitors in 2003, which could be a response by the Balinese to make offerings at the Menjangan temples in response to the 2003 bombings.

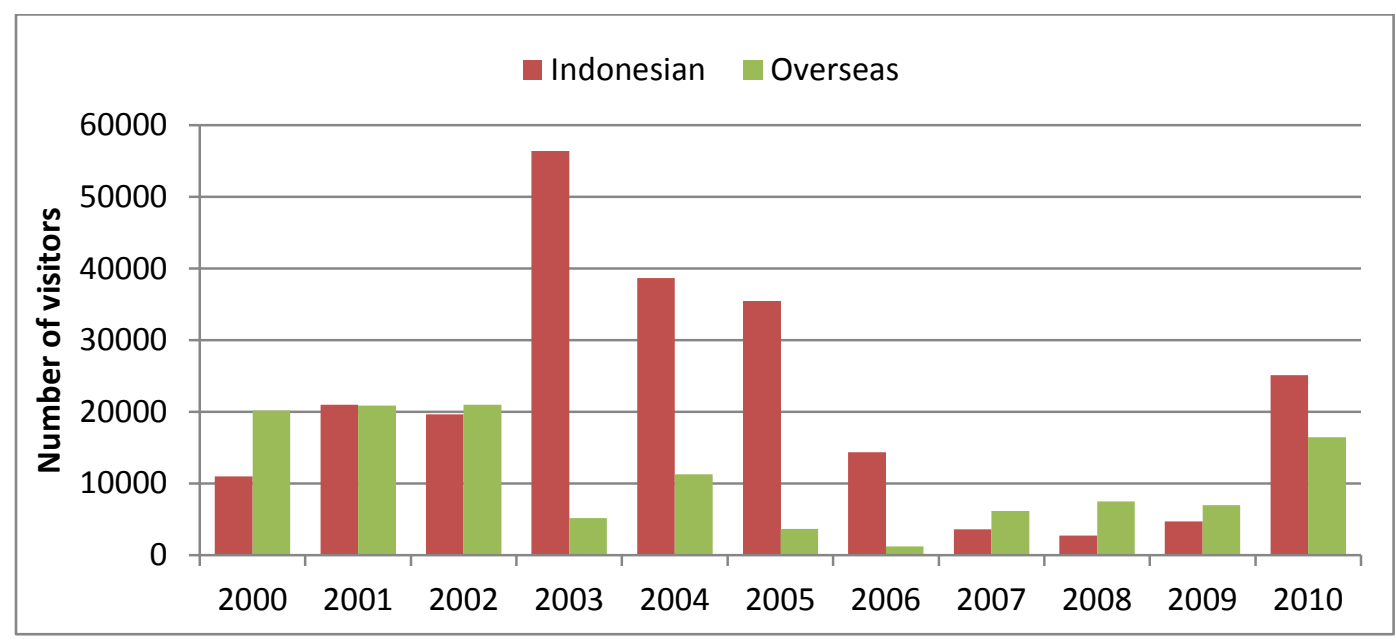

Figure 13. Number of Indonesian and overseas visitors to Menjangan Island from the years 2000 to 2010.

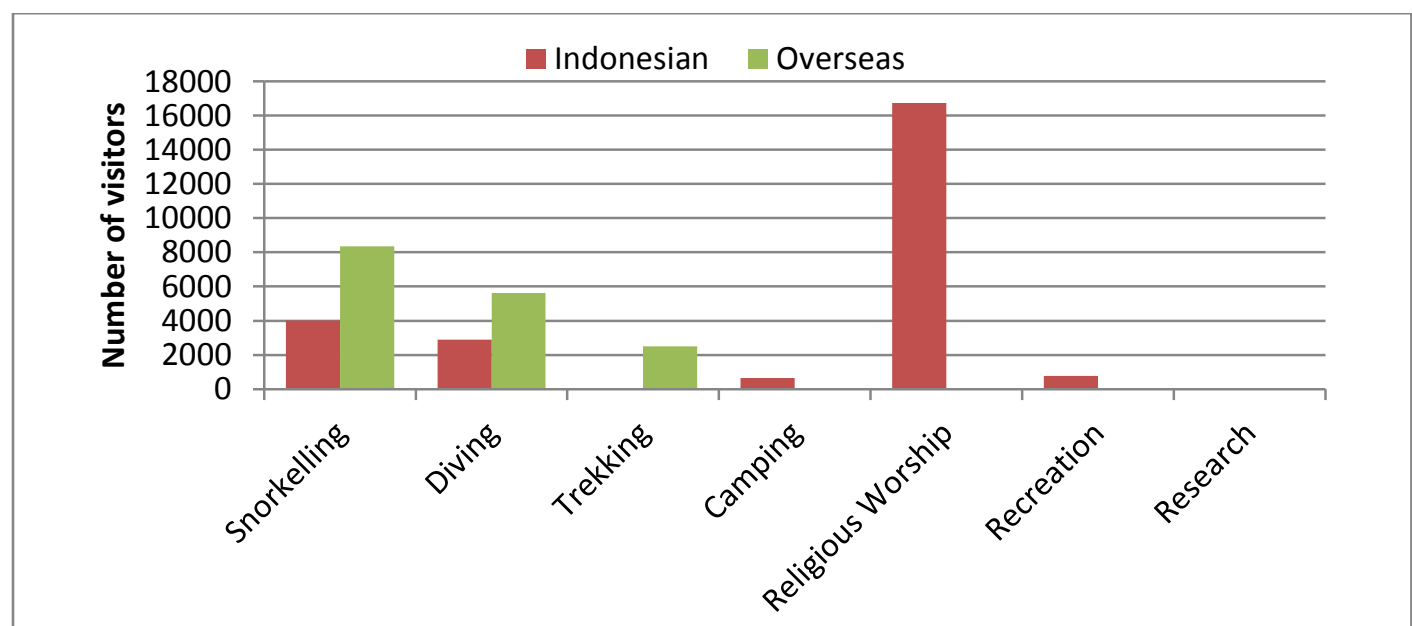

Figure 14.Numbers of visitors per activity in 2010.

\section{History of Patrolling \& Enforcement of the Utilization Zone}

Bali Barat National Park. BBNP is particularly lacking in sufficient resources, capacity and manpower to effectively manage the Marine Reserve at Menjangan Island. While there is a fee to enter Menjangan Island for walking, snorkeling, diving or praying, the budget allocated by central government for patrolling covers the costs of only two days a year (pers. comm.). Thus the solution for patrolling the seas is not likely to come from the Government at this time.

To combat this problem of hostile fishermen refusing to honor the rules, WWF attempted a program from 2003 to 2008, which encouraged local people to become involved in coral monitoring and patrolling. They formed a co-management forum called "Coastal Care Community Communication Forum of Bali Barat National Park”, FKMPP-TMNBB (Forum Komunikasi Masyarakat Peduli Pesisir, Taman Nasional Bali Barat). The program was successful as long as WWF was present and paying for patrols, but because of the lack of continued monetary support, it was not sustainable (pers. comm.). 
BBNP officials described a significant event that discouraged their patrol of the waters in 2008. On this day, BBNP impounded the crew of a fishing boat from Madura, which was illegally fishing in BBNP. Days later, approximately 200 Madurese boats arrived at Menjangan Island to liberate the fishermen and simultaneously the facilities at the island were burned and smashed. The infrastructure was never restored and the memory holds the local people in some paralysis to acquiesce to outside fishermen so as not to be harmed.

In 2011, a few fishermen who are impassioned to stop the destructive fishing organized themselves to patrol Menjangan Island at their own cost. On $5^{\text {th }}$ March, several local fishermen banded together and spent the day of Nyepi (a 24 hour period of silence during which the Balinese meditate on their past year) at Menjangan Island. This is a Balinese ceremony and is not shared by the neighboring Javanese or Madurese and thus the island is subject to people from outside Bali who take advantage of this quiet day to raid the reefs. The local fishermen expected this, but were unable to prevail because the armed fishermen ran them onto the island, forcing them to hide (pers. comm.)

Local Authorities. Bali is divided into kabupaten (districts), kecamatan (municipalities) and kelurahan or desa (villages). Traditionally, a banjar (equivalent to a neighborhood) has the authority recognized by Central Government since 1979, to control the inhabited land within a desa using its own security forces called the pecalang. Membership to the banjar is mandatory for each married man who then represents his family. While Menjangan Island is located within the boundaries of BBNP, it is also governed by the kabupaten of Singaraja, as well as Labuan Lalang banjar and Banyuwedang banjar. Each of these governing bodies also has a priest that oversees the temples and worship at Menjangan Island. And finally, each banjar has its own pecalang. In some coastal areas of Bali, pecalanglaut are the security forces for the sea and have been incorporated into coral reef protection programs, for example, by Reef Check Indonesia in their establishment of a marine reserve at Teja Kula in north Bali (Sartin et al., 2010).

\section{Conservation Initiatives - Friends of Menjangan}

It is clear that the future of Menjangan Island and its coral reef relies on involvement of all the stakeholders including BBNP, NGO's, and the local community. In support of this program, Biosphere Foundation and Yayasan Dwi Asih Sejahtera (a local non-profit organization based in BBNP) launched a conservation initiative called "Friends of Menjangan" to steward and protect the island and its reef. All activities are approved by BBNP and carried out by the local community with funding from able stakeholders. The community embraced this concept with enthusiasm and its inaugural event was held on May $6^{\text {th }}$ and $7^{\text {th }} 2011$ at Labuan Lalang and Menjangan Island. Members of all stakeholders were present including central government, local government, temple priests, fishermen, schools, local NGOs, international NGOs, resorts, tourists and the media.

The overall objective of Friends of Menjangan is to coordinate a comprehensive community based conservation program involving everyone who cares about Menjangan Island. Its long-term objectives include:

- Designing and implementing a maintenance program for the Menjangan Island mooring buoy system and installing additional buoys.

- Eradicating destructive fishing by implementing educational outreach programs and cooperative patrols between local government, central government and the fishermen at Menjangan Island.

- Initiating educational programs for dive and snorkel guides, to create a center of excellence at Menjangan Island in managing tourism.

- Implementing regular beach and reef cleanups.

- Involving the priests and community to remove all garbage from the temples after each ceremony.

- Installing of waste and garbage management and plastic recycling.

- Creating educational programs for local schools about sound conservation practices 


\section{CONCLUSION}

Marine Protected Areas (MPAs) can be effective in preventing coral losses compared to a global trend in declining coral cover worldwide (Selig and Bruno, 2010). Approximately 27\% of the world's reefs are within MPAs, but only 6\% are managed effectively (Burke et al., 2011). While Menjangan Island has benefited from the act of being declared an MPA in 1984, it is still threatened by visiting small boats using anchors instead of moorings, overfishing and climate change. Given the forecast of increasing severity and frequency of bleaching events, improved protection to the coral reef of Menjangan Island must be enforced to help increase the reef's resilience to climate change and keep this area a reservoir for biodiversity as well as economic viability for the people of NW Bali. The future of its wellbeing thus depends on collaborative effort by all its stakeholders. This inspired a community-based project called "Friends of Menjangan" which brings together the different interested parties. Other such programs engaging community conservation are showing that this is a solution for far-reaching change (Fabinyi, 2010). It is the people who know, use and love their land and sea that will persist to protect it, despite all difficulties, and it is the role of NGOs and scientists to encourage and help steward an intelligent approach.

\section{ACKNOWLEDGEMENTS}

We wish to honor the Menjangan Island fishermen who have organized themselves to sustain a decade-plus agreement not to fish at Menjangan Island and who befriended our team to help further their ability to steward the reef. It is their dedication and willingness to conserve Menjangan Island that has inspired Friends of Menjangan. We also wish to thank the Ministry of Forestry, BBNP and Dr. David Makes that invited our involvement and all the many hands that came before us and were inspired to initiate conservation programs. Finally we wish to honor the crew of yacht Mir who worked with the science and conservation teams and provided the backbone of our ongoing program.

The Marisla Foundation, Royal Geographical Society and Roy A. Hunt Foundation funded the research study with participation by Wildlife Conservation Society and College of Charleston, The Threshold Foundation, Ward Family Foundation, Kopcho Family Foundation, Cameron Foundation and Sustainable Management Group supported the conservation initiatives.

Biosphere Foundation's 2011 research was conducted under research license 076/SIP/FRP/SM/III/2011 issued by RISTEK (Kementerian Riset Dan Teknologi Republik Indonesia). With thanks to Professor Suharsono and Dr Djoko Hadi Kunarso of LIPI, the Indonesian Institute of Sciences, for their support of this work.

\section{REFERENCES}

Allen, G.R. and T.B. Werner. 2002. Coral reef fish assessment in the 'coral triangle' of southeastern Asia. Environmental Biology of Fishes, 65: 209-214.

Anon. n.d. "NOAA Coral Reef Conservation Program Coral Triangle Region”, http://coralreef.noaa.gov/aboutcrcp/international/ctr/. page consulted 20 July 2012.

Anon. 2010. "Only 6 pct of excellent coral reefs remains in RI, Waspada Online.” http://www.waspada.co.id/index.php?option=com_content\&view=article\&id=138421:only-6-pctof-excellent-corral-reefs-remains-in-ri\&catid=30:english-news\&Itemid=101. page consulted 20 July 2012.

Boekschoten G. J., M. Borel Best, and K. S. Putra. 2000. Balinese reefs in historical context. Proceedings $9^{\text {th }}$ International Coral Reef Symposium 23-27 October 2000, Bali, Indonesia.

Bryant D., L. Burke, J. McManus and M. Spalding. 1998. Reefs at risk: a map-based indicator of threats to the world's coral reefs. 
Burke L., K. Reytar, M. Spalding, and A.Perry. 2011. Reefs at Risk Revisited. World Resources Institute. Washington, $130 \mathrm{p}$.

Burke, L., E. Selig, and M. Spalding. 2002. Reefs at risk in Southeast Asia. World Resoruces Institute, www.wri.org. Washington D.C.72 p.

Dirhamsyah, J. Subijanto, H. A. Susanto, S. Nurhakim, I. Amin, L. Napitupulu, S. Timotius, Nurlaili, E. Damayanti, P. Yudiarso, Wen Wen, R. Alhanif, A. Budiarto, and H. Kushardanto. 2012. The State of the Coral Triangle in Indonesia, Coral Triangle Marine Resources: Their Status, Economies, and Management. Indonesian National Coordinating Committee of Coral Triangle Initiative, http://www.coraltriangleinitiative.org/ .

Fabinyi, M. 2010. The Intensification of Fishing and the Rise of Tourism: Competing Coastal Livelihoods in the Calamianes Islands, Philippines. Human Ecology 38:415-427

Giri, C., E. Ochieng, L. L. Tieszen, Z. Zhu, A. Singh, T. Loveland, J. Masek, and N. Duke. 2011. Status and Distribution of Mangrove Forests of the World using Earth Observation Satellite Data. Global Ecology and Biogeography, 20, 154-159.

Hatziolos, M. E., A. J. Hooten \& M. Fodor. 1998. Coral Reefs: Challenges and Opportunities for Sustainable Management: Proceedings of an Associated Event of the Fifth Annual World Bank Conference on Environmentally and Socially Susutainable Development. World Bank Publications.

Hoegh-Guldberg, O., H. Hoegh-Guldberg, J.E.N. Veron, A. Green, E. D. Gomez, J. Lough, M. King, Ambariyanto, L. Hansen, J. Cinner, G. Dews, G. Russ, H. Z. Schuttenberg, E. L. Peñaflor, C. M. Eakin, T. R. L. Christensen, M. Abbey, F. Areki, R. A. Kosaka, A. Tewfik, and J. Oliver. 2009. The Coral Triangle and Climate Change: Ecosystems, People and Societies at Risk. WWF Australia, Brisbane, 276 p.

Hoeksema, B. W., and K. S. Putra. 2000. The Reef Coral Fauna of Bali in the center of Marine Diversity. Proceedings $9^{\text {th }}$ International Coral Reef Symposium, Bali, Indonesia 23-27 vol:1: 173-178

Hoey A. S., and D. R. Bellwood. 2009 Limited functional redundancy in a high diversitysystem: single species dominates key ecological process on coral reefs. Ecosystems 12:1316-1328.

Kartarahardja, A. 2009. Illegal Fishing Destroys Menjangan Coral Reefs. The Jakarta Post 23 April 2009.

Kartika, D. 2011. A socioeconomic study of the Banyuwangi and Madura communities on the marine resources of Menjangan Island, Bali Barat national Park, Indonesia. Unpublished report, Bali, Indonesia.

Kertaharja A. 2009. Mass bleaching in 30\% of northern Bali reefs. The Jakarta Post $22^{\text {nd }}$ June 2009

McManus, J. W., and R. B. Reyes. 1997. Effects of Some Destructive Fishing Methods on Coral Cover and Potential Rates of Recovery. Environmental Management 21: 1: 69-78.

Polunin N. V. C., M. K. Halim, and K. Kvalvagnaes. 1983. Bali Barat: An Indonesian Marine Protected Area and its Resources. Biological Conservation 25: 171-191.

Putra K. S., and A. Widyastuti. 1999. Laporan Reef Check in Indonesia. WWF Wallacea Bioregional Program, Bali, Indonesia.

Sartin, J., D. Purwita, D. Sri, and R. H. Pamungkas. 2010. Annual Report 2010 Reef Check Foundation Indonesia. http://reefcheck.org/PDFs/reports/Indonesia\%202010.pdf. Page consulted 20 July 2012.

Selig E. R., and J. F. Bruno. 2010. A Global Analysis of the Effectiveness of Marine Protected Areas in Preventing Coral Loss. PLoS ONE 5(2): e9278. doi:10.1371/journal.pone.0009278.

Spalding, M. D., C. Ravilious, and E. P. Green. 2001. World Atlas of Coral Reefs. UNEP-WCMC, Cambridge.

Veron J.E.N. 2008. Mass extinctions and ocean acidification: biological constraints on geological dilemmas. Coral Reefs. 27: 459-472. 